University for Business and Technology in Kosovo

UBT Knowledge Center

UBT International Conference

2017 UBT International Conference

Oct 27th, 1:00 PM - 2:30 PM

\title{
Renewal of a Housing District from the sixties in Budapest
}

\author{
János Gyergyák \\ University of Pécs, gyergyak.janos@mik.pte.hu \\ Erzsébet Szeréna Zoltán \\ University of Pécs, betty.zoltan@mik.pte.hu \\ Bence Gál \\ University of Pécs, galbence.arch@gmail.com \\ Anett Gál-Mózes \\ University of Pécs, mozes.anett@gmail.com
}

Follow this and additional works at: https://knowledgecenter.ubt-uni.net/conference

Part of the Architecture Commons

\section{Recommended Citation \\ Gyergyák, János; Zoltán, Erzsébet Szeréna; Gál, Bence; and Gál-Mózes, Anett, "Renewal of a Housing District from the sixties in Budapest" (2017). UBT International Conference. 9. \\ https://knowledgecenter.ubt-uni.net/conference/2017/all-events/9}

This Event is brought to you for free and open access by the Publication and Journals at UBT Knowledge Center. It has been accepted for inclusion in UBT International Conference by an authorized administrator of UBT Knowledge Center. For more information, please contact knowledge.center@ubt-uni.net. 


\title{
Renewal of a Housing District from the Sixties in Budapest
}

\author{
János Gyergyák ${ }^{1}$, Erzsébet Szeréna Zoltán ${ }^{1}$ \\ Faculty of Engineering and Information Technology, University of Pécs, \\ Boszorkány str. 2, 7624 Pécs, Hungary \\ \{gyergyak.janos ${ }^{1}$, betty.zoltan $\left.{ }^{2}\right\} @$ mik.pte.hu ,
}

\begin{abstract}
At the time of its construction the housing estate József Attila (1956-1963) in Budapest was a sample project (installation, interior spaces, new structures and materials) which has been obsoleted in the last 50 years. After winning the architectural and urban competition using openminded architectural thinking that can make the housing estate a new role model again increasing existing values and give new ones, the paper presents the principles of design which could be standard for neighborhoods of similar history.
\end{abstract}

Keywords: renewal, housing estate, urban, value adding

\section{Introduction}

After World War II Budapest's building stock was in a very poor state., and with the nationalization of industry and land, the priority was set on developing the new industry and reconstructing the city. For that work, man power was needed - which made workers to move in towns from the agricultural areas. This resulted in the lack of apartments what made the government to invest in large scale housing estate developments, and there were years when over 100.000 new apartments were built [1]. Nearly 20\% of Hungary's 4.3-million-unit housing stock was built with dated industrialized technology - as prefabricated, block, cast, and tunnel-formwork buildings. These apartment blocks solved a majority of the housing shortage furthermore they were successful: new homes had all those comforts, which the previous housing stock were only partially equipped with (tap water, sanitation, waste water drainage, electricity, gas oven and heating) [2]. The housing district József Attila was a special project of about 10.000 apartments for 38.000 inhabitants, on the site of the former slums Maria Valeria, and was developed in 5 main periods between 1957 and 1981 [3]. The building periods used preferably a special typology of apartment blocks and the final layout of the urban development was designed in a rather organic way, with asymmetrical configuration of streets and roads and a lot of green space. This is what makes the neighborhood even after 50 years a desired place to live, though necessity of the rehabilitation is inevitable. The aim of the architectural and urban competition set the focus on the strengthening of the local identity in this town scaled housing estate and the establishment of a community building as a further step. In our concept the program was broadly interpreted in the center of the housing estate in the form of a "paved" and a "green" community space. 


\section{The main issues within the district}

As the József Attila neighborhood development was a great success according to its nearness to the city center, the quick accessibility through the subway, a big ratio of the inhabitants is now the owner of the condo where they moved in as the first tenants in the sixties. The change of the generations is getting visible, but the fact, that $90 \%$ percent of the condos is a 1 bedroom apartment, makes young families with children to move on even though daycare and school are also provided on the site.

These facts brought the municipality to make the first step to define the future of this building complex, and finding the best solutions for it in the form of an open architectural and urban competition.

\section{The new identity of the district}

Preservation and activation of the existing green surface plays the major role as this is till today the most often emphasized main value of the area. By adding new land system and community functions the „delimitation” of the external boundless spaces is solved.

With the creation of a multi layered community area system we activate community life: strengthen the relations among neighborhoods with multiple levels of space usage. At the bottom of the hierarchy is the staircase community, which is in charge of the immediate surrounding of the house, the block community maintains the external community space - which is given into use by the local government and at the top there is the urban space maintained by local government.

With the design of the missing or under-utilized housing functions, as the cultural, recreational and commercial (market) surfaces for the housing estate (about 20,000 people) additional attractiveness is established within a larger, peripheral green space.

To develop the public transport system and the quality of its nodes is essential, and subsidizing the shared traffic system might be the solution to the emerging parking problems as establishing a better infrastructure of pedestrians and bicycles in order to reduce car dependence on the housing estate.

With the unified possibilities for extensions of the existing building stock we respect the private property, and prepared the possible later extensions in a way which the local community can stand by along with the uniform image of the housing estate.

At the time of the construction of the housing estate (1956-1963) it was a sample project (installation, interior spaces, new structures, new materials) which has been obsoleted in the last 50 years. Our goal is to use architectural thinking instead of the commercial, mediocre solutions that can make the housing estate a new model and increase their value.

\section{Development concept of the community areas}

The main issue of the development in this town scaled housing estate is the way of strengthening the local identity and the establishment of a community building as a further step. In our concept the program was broadly interpreted in the center of the housing estate in the form of a "paved" and a "green" community space. While the "paved" community spaces serve local needs, the "green" development can appeal in a broader sense - on district or city (recreational) level.

The primary value of the housing estate is the woody, grassy green areas which should be preserved. Though the size of the green area is extremely significant, its condition is outdated, the maintenance can be a heavy burden on the local government.

A multilevel division of the existing green space system was designed and should be maintained by local residents, working together as a "block community" or owners of the 
"residential community" garden, based on the landscape architectural and archaic principles adopted by the housing estate (community planning and intensive involvement of residents and communities).

\section{Renewal concept of the pavilions}

The pavilions play an important role in the neighborhood, as many services are offered in this kind of built structures. The existing, shabby and uncomfortable ones need to be transformed into easily maintainable units with a fresh and modern architectural character and a possibly flexible layout for the function. Two different basic layouts were offered (linear and a Y-shaped) including covered decks which provide transitional spaces for the commercial functions.

\section{Transportation, Parking, Noise protection and other developments}

The issues of transportation, parking and noise protection were handled in a complex manner. The area is easily approachable, but future sustainability requires more pedestrian, bicycle and community traffic developments. For the development of pedestrian zones, new links were designed among the major public transport hubs, commercial and service units and "attractions". Pedestrian traffic can be most efficiently reinforced by smaller distances between the pavilions (active space, active environment). Community transport can be more functional if some stops are moved to new, structurally important and accessible locations. We also recommend converting priority hubs (metro, tram line and "enclosed" and "green" central areas) into multimodal nodes, where pedestrian, metro / tram / bus, parking and bicycle storage / rental surfaces are developed simultaneously. In order to solve the parking problems in the area, 6 new parking spaces were designed for the inhabitants - mainly in the form of underground parking to preserve the green image and $5 \mathrm{P}+\mathrm{R}$ parking lots were assigned to the existing metro stops, proposed new tram stops and planned traffic roadside development.

\section{The new identity of the housing blocks}

As the apartments were built more than 50 years ago, and the estimated lifespan of the main structure is about 80-120 years, they can serve another generation of inhabitants. In case of prefabricated blocks of flats, the renovation costs are only a fraction of the costs of a new building. Looking at this from an economical viewpoint, the importance of this fact is very significant. The retrofit - especially the thermal insulation - is expected to increase the remaining lifespan of the building by approximately 20 years [4] Though the structure can be considered as solid, but the sub-system components are definitely over dated, as their normal and sustainable maintenance suggests 5-30 years for replacement [1].

\section{Concept of extending the living area - without eliminating greenery}

The prefab apartments have higher utility costs in comparison with those with individual heating solutions. Thermal insulation, replacement of the windows, installation of heating meters can reduce those costs, and result in better comfort, and lower maintenance costs. Though there is a subsidized program for complex housing estate rehabilitation in Hungary, as all the owners have to stand for at least $10 \%$ contribution of the costs, which makes the overall refurbishment almost 
impossible in the case of units with retired and elderly. As it is a very complex sociological problem, which cannot be solved merely by architects but alternative suggestions can be a solution.

It was and still is a widely known fact that the smallest $\mathrm{p}$ refabricated apartments were built in Hungary. The reason of it can be found in some very ideological vision about the way people were expected to live. One solution might be the personalized reapportion of the interior spaces [5].

Our goal was instead of dealing with interior design issues giving an architectural and urban solution to today's well-known problems, though at the start of the design process an overall analysis of the existing outdated layouts of the condominiums was inevitable. Diverse possibilities for extensions both horizontally and vertically were investigated.
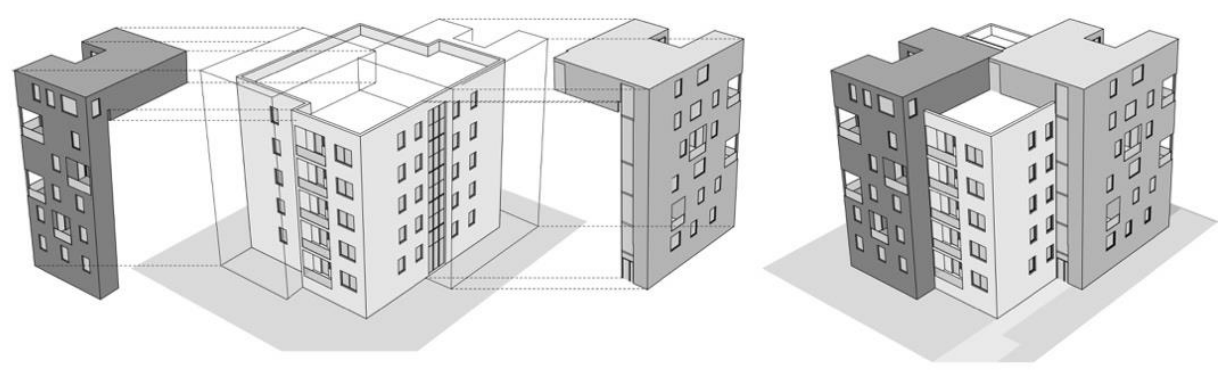

Fig. 1. Basic scheme for the extension of house type K

The vertical extension has a major issue as no exact data according foundation, physical properties of soil, especially those properties that affect its ability to bear weight were available, so the decision fell upon a solution, which minimizes the extra loads of the existing structure, creating and almost individual skeleton structure (as shown in Fig.1), which was essential to provide the desired flexibility. Flexibility is the key aspect of sustainability - especially in a situation, where the needs might be considerably different.

\section{How to make it available for all}

In our winning concept two different design programs were offered for the house types $\mathrm{K}$ and $\mathrm{T}$. These types and their variations give approximately 40 percent of the apartments, and in most cases on 1 or 2 sides it is possible to build an addition without harming the greenery. The raster of the skeleton structure can extend the small 1 to 2 room apartments with some more living space - and if there is no extra room needed, it can be used as balcony. In Fig. 2 four possible layout schemes are displayed starting with the original layout and the design of 2 additional apartments on the roof top. 

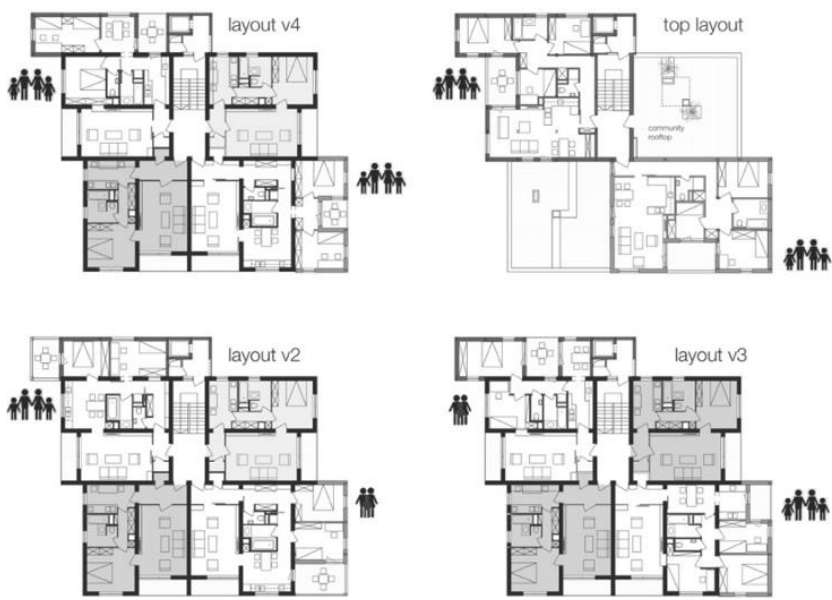

original layout
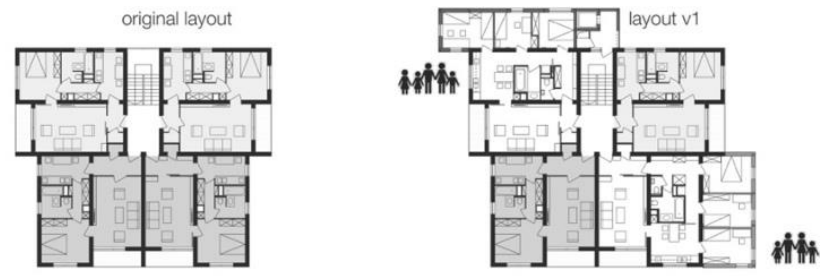

Fig. 2. House type $\mathrm{K}$ extended with an elevator, extra rooms and balconies, and 2 additional apartments on the top

As it is rather unlikely, that the owners of the condos can finance, the idea that the rooftop can be given to that contractor, who builds the top new apartments, for which the skeleton would be the solid base. The existing apartments could be extended by the structure actually for free, and depending on the financial background and the actual needs, they could develop their own apartment in stages, using the defined cladding for the exterior.

The building regulations in Hungary only allow the vertical extension if an elevator is also available - so the new block of the elevator shaft is also established outside of the original boundaries of the house. With this solution the complex accessibility is unfortunately not provided but it makes life more comfortable.

\section{The future of the project with community planning}

The process of finalizing the plans has started. The tool of community planning will be used to harmonize the wish and interest of the different levels of the communities with the local businesses, in the frame of the available budget of the development. This process is welcomed because community planning becomes a truly powerful force for positive and sustainable change [6]. Therefore design process can be longer, but the environment can be matched with broader interest and later the local communities will treat the area instead of the local government. 


\section{References}

1. Birghoffer P., Hikisch L. Reconstruction of prefabricated residential buildings, (in Hungarian) Müszaki Könyvkiadó, Budapest, (1994)

2. Dési A. Prefabricated guide, (in Hungarian) Építésügyi Tájékoztatási Központ, Budapest, (1996)

3. Fekete E. (ed): József Attila neighborhood (in Hungarian), Lakóterv, Budapest, (1963) 5-6

4. Hrabovszky-HorvátH S., Szalay Zs.: Environmental Assessment of a Precast Concrete Building Stock In A Time Perspective. Environmental Engineering and Management Journal November 2014, Vol.13, No. 11, 2797-2804

5. Borsos, Á.: Living Spaces - Prefabricated Apartments. Pollack Periodica, Vol.9, Nr2 2014 59-66

6. “About community planning" http://www.communityplanning.net/aboutcp/aboutcp.php. (17.10.2017.) 